\title{
Esophageal inlet patch: Demographic and endoscopic characteristics of patients and review of the literature
}

\author{
Özofageal inlet patch: Hastaların demografik ve endoskopik karakteristikleri ve litaratürün gözden \\ geçirilmesi
}

(D) ibrahim Hakkı KÖKER¹, (D) Nurhan ŞAHIN²

Departments of ${ }^{1}$ Gastroenterology and ${ }^{2}$ Pathology, Bezmialem Vakif University School of Medicine, İstanbul

\begin{abstract}
Background and Aims: An esophageal inlet patch is crucial in swallowing difficulty, laryngopharyngeal reflux symptoms, and rarely in the etiology of proximal esophagus adenocarcinoma. We aimed to evaluate the endoscopic and demographic features of patients with esophageal inlet patch during endoscopic evaluation and compare them with those of the literature. Materials and Method: Between January 2017 and January 2021, we evaluated the age, gender ratio, inlet patch size, and number along with the other endoscopic findings in patients with proximal esophageal inlet patch. Results: Overall, 53 patients (women, 36 (68\%); mean age, $46.3 \pm 15.8$ years; range, $19-83$ years) were included the study. Only 13 patients $(24.5 \%)$ had specific symptoms of esophageal inlet patch. The median esophageal inlet patch size was $7.0 \mathrm{~mm}$ in women (range, 4-30), while it was 8 $\mathrm{mm}$ (range, 5-20) in men. The median inlet patch number was 1 in both sexes (range, 1-3 in women, 1-2 in men). Forceps biopsy was possible in $30(56.6 \%)$ patients. We found no additional esophageal pathology in 45 (84.9\%) patients, normal lower esophageal sphincter in 39 (73.5\%), incompetent lower esophageal sphincter in 14 (26.4\%), hiatal diaphragmatic hernia in $1(1.8 \%)$, and endoscopic antral gastritis in 29 (55.7\%) patients. Twelve (54.5\%) of 22 endoscopic biopsies were positive for Helicobacter pylori. We detected esophageal inlet patch in the distal esophagus in 2 (3.7\%) patients. Conclusion: Esophageal inlet patch was more common in women, unrelated to gastroesophageal reflux disease, and most patients were asymptomatic, with a median size of $8 \mathrm{~mm}$ (range, 4-30), with no gender difference. Moreover, inlet patch size was not associated with presence of symptoms. Evidence of malignancy in the biopsied inlet patches was not observed.
\end{abstract}

Key words: Endoscopy, inlet patch, heterotopic gastric mucosa

\section{INTRODUCTION}

The inlet patch (IP) is an island of heterotopic gastric mucosa and was first described by Schumidt in the cervical esophagus, but it's pathogenesis has not been elucidated yet $(1,2)$. Globus sensation, laryngopharengeal reflux and dysphagia are commonly reported symptoms of esophageal IP $(3,4)$. Globus is a nonpainful sensation of a lump or foreign body in the throat which frequently improves with eating and swallowing (5). Globus diagnosis requires the absence of structural lesions as esophageal $I P$, gastroesophageal reflux disease (GERD) or motor disorders. For this reason, the exclusion of IPs in the di-

Correspondence: İbrahim Hakkı Köker

Bezmialem Vakif University School of Medicine,

Department of Gastroenterology 34093, Fatih, Istanbul, Turkey

E-mail: koker34@yahoo.com
Giriş ve Amaç: Özofageal inlet patch yutkunma zorluğunda, laringofarengeal reflü semptomlarında ve nadir de olsa proksimal özofagus adenokarsinom etiyolojisinde önemlidir. Amacımız endoskopik değerlendirme sırasında özofageal inlet patch tespit ettiğimiz hastaların endoskopik ve demografik özelliklerini değerlendirmek ve literatürle karşılaştırmaktı. Gereç ve Yöntem: Ocak 2017-Ocak 2021 tarihleri arasında üst gastrointestinal endoskopik değerlendirmede özofagusta inlet patch saptanan hastaların yaş, cinsiyet, inlet patch boyutları ve sayısı ile hastalarda saptanan diğer endoskopik bulguları değerlendirdik. Bulgular: Toplam 53 hastanın 36'sı (\%68) kadındı. Yaş ortalaması $46.3 \pm$ 15.8, değer aralığı (19-83) yıldı. Hastaların 13'ü inlet patch tanısı açısından semptomatikti. Özofageal inlet patch median boyutları kadınlarda 7.0 mm, değer aralığı (4-30) iken; erkeklerde 8 mm, değer aralığını (520) saptadık. Her iki cinsiyette median inlet patch sayısı 1, değer aralığı kadınlarda 1-3, erkeklerde 1-2 idi. Hastaların 30'unda (\%56.6) forseps biyopsisi yapılabildi. Hastaların 45'inde (\%84.9) ilave özofagus patolojisi saptamadık, 39'unda (\%73.5) alt özofagus sfinkteri normal, 14'ünde (\%26.4) incompetant, 1 (\% 1.8) hastada ise Hiatal Herni saptadık. 29 (\%55.7) hastada endoskopik antral gastrit bulgusu saptadık. 22 endoskopik biyopsinin 12'sinde (\%54.5) Helicobacter pylori pozitifti. Ayrıca 2 (\%3.7) hastada özofageal inlet patch distal özofagus yerleşimli olarak tespit edildi. Sonuç: Özofageal inlet patch kadınlarda daha sıktı, gastroözofageal reflü hastalığı ile ilişkisizdi ve çoğu hasta asemptomatikti. Özofageal inlet patch'lerin median boyutları 8 mm, değer aralığı (4-30) idi, kadın erkek arasında fark saptamadık. Inlet patch boyutları ile semptom varlığı arasında da ilişki kuramadık. Biyopsi alınan inlet patchlerin hiçbirisinde malignite bulgusuna rastlamadık.

Anahtar kelimeler: Endoskopi, inlet patch, heterotopik gastrik mukoza

agnosis of globus is considered among the mandatory factors in the ROME IV criteria (6). When IP is detected in the proximal esophagus, acid suppressive therapy improves the symptoms due to esophageal IP (7). There are also studies showing that argon plasma coagulation is successful in esophageal IP (8-10).

The aim of our study is to evaluate the endoscopic and demographic characteristics of patients with IP detected during endoscopic evaluation and to compare them with the literature retrospectively.

Köker IH, Sahin N. Esophageal inlet patch: Demographic and endoscopic characteristics of patients and review of the literature. The Turkish Journal of Academic Gastroenterology 2021;20:117-122. DOI: 10.17941/agd.982255

Manuscript received: 23.06.2021 • Accepted: 03.08.2021 


\section{MATERIALS and METHOD}

\section{Study Design and Participants}

We evaluated the endoscopic and demographic characteristics of 53 patients with IP, most of them were found in the proximal esophagus, who applied to the Endoscopy Unit of Bezmialem University Gastroenterology Clinic between January 2017 and December 2020. All endoscopic procedures were done by the same endoscopist (IHK). Demographic data, medical history, gastrointestinal endoscopic findings of these patients retrieved from the electronic medical records. The study protocol was approved by the local ethics committee for this retrospective study (Bezmi Alem University, Ethics Committee of Non-interventional Studies, 16.02.2021, 03/62).

\section{Endoscopic Evaluation and Biopsies}

Upper gastrointestinal (GI) endoscopy was performed by a single endoscopist using a frontal view videoendoscopes [Fujinon endoscope K017, (Fujinon (Europe) Willich, Germany] following anestesia sedation. Inlet patch was defined as salmon-red mucosa with well-defined borders (Figure 1). The size of IP measured under the guidance of open $5 \mathrm{~mm}$ biopsy forceps (Figure 1B).

Forceps biopsy could not be taken from 23 patients due to various reasons including coagulopathy. However the- se patients were included in the study as their lesions were compatible with IP. In the remaining 30 patients, 1 or 2 biopsies were taken depending on the technical position of the lesion. Biopsies were taken from esophagus, corpus and antrum, based on the discretion of the physician if necessary. Other endoscopic findings were also documented.

\section{Histopathological Assesment}

Histological specimens were obtained by biopsy forceps. Biopsy specimens taken from endoscopically diagnosed esophageal IPs were stained with haematoxylen-eosin and Toluidin-O.

\section{Statistical Analysis}

All statistical analyses were performed using SPSS Statistics software version 25 (IBM Corp., Armonk, NY, USA). Categorical variables were expressed as number (\%) and comparison between groups were performed using chi-square or Ficher's exact test, as appropriate. Kolmogorov-Smirnov test and Shapiro-Wilk tests showed a non-normal distribution of all data. Descriptive statistics were presented using medians and range values for non-normally distributed and ordinal variables. Mann-Whitney test was used in comparisons of median values with nonparametric distribution. A two-tailed p-value < 0.05 was considered as significant.

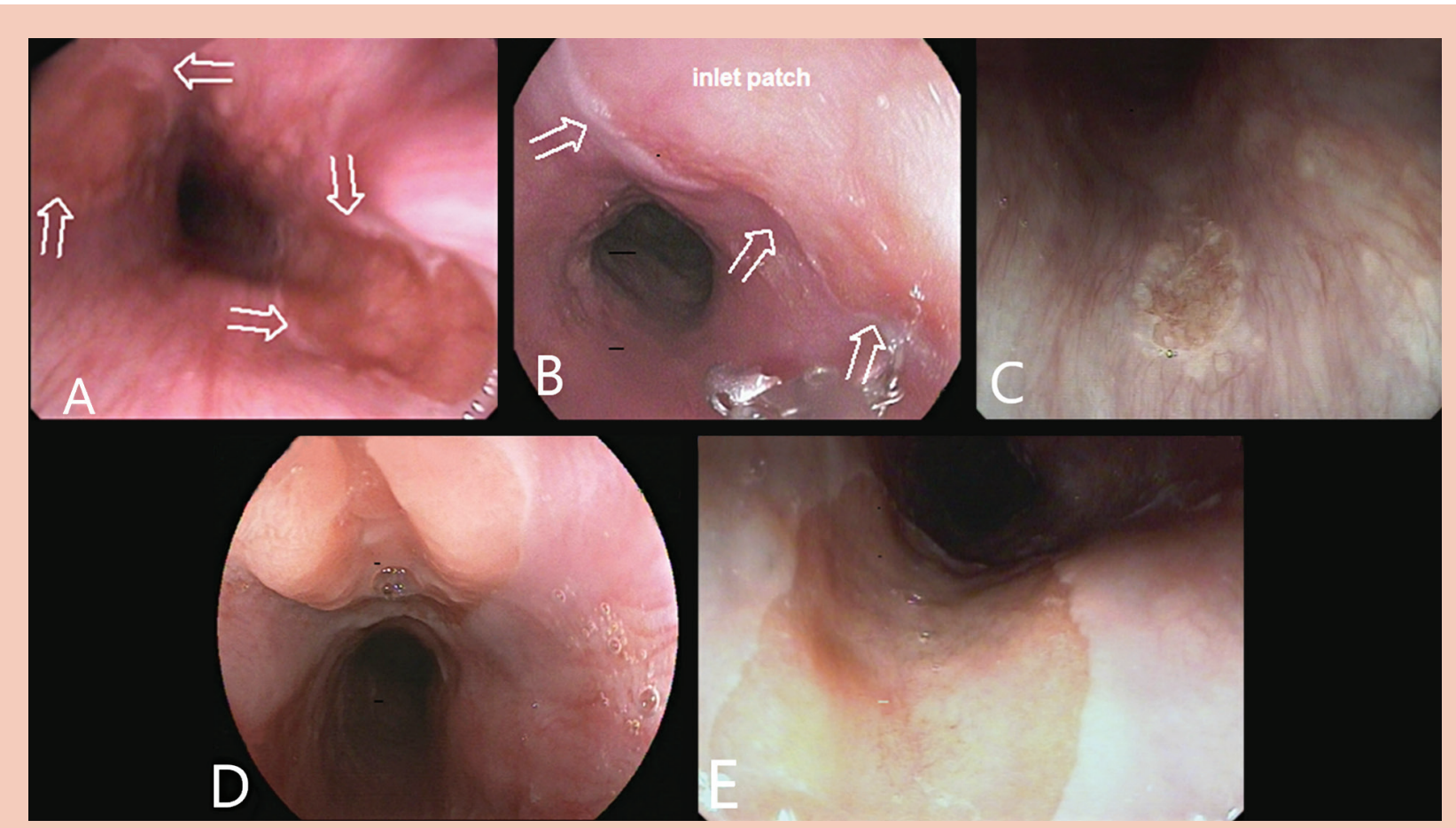

Figure 1. Various type endoscopic images of heterotopic gastric mucosa (IP). A. Multiple, B. Comparison of IP size with forceps size, C. Small, D. Lobulated, E. Tongue shaped like Barrett. 


\section{RESULTS}

\section{Patient Characteristics}

The average age, range, number of patients with specific symptoms and the number of patients with globus sensation in patients with IP detected in endoscopic evaluation are shown in Table 1.

\section{The Outcomes and Coexisting Lesions According to Gender}

In patients with endoscopic IP, biopsies according to gender, pathological confirmation, and other pathological findings detected in endoscopy are shown in Table 2 according to the frequency rates.

\section{Table 1. Characteristics of patients with endoscopic esophageal IP diagnosis}

\begin{tabular}{|c|c|c|c|}
\hline & Female $(n=36,68 \%)$ & Male $(n=17,32 \%)$ & All $(n=53,100 \%)$ \\
\hline Age, years mean $\pm S D$ & $45.6 \pm 16.5$ & $48.0 \pm 14.6$ & $46.3 \pm 15.8$ \\
\hline Age, range & $19-75$ & $23-83$ & $19-83$ \\
\hline *Specific symptoms n (\%) & $10(27.7)$ & $3(17.6)$ & $13(24.5)$ \\
\hline Globus & 7 & 2 & 9 \\
\hline
\end{tabular}

Table 2. The outcomes of patients with endoscopic IP diagnosis according to gender

\begin{tabular}{|c|c|c|c|}
\hline & Women $(n=36)$ & Men $(n=17)$ & All $(n=53)$ \\
\hline IP size mm, median (range) & $7.0(4-30)$ & $8(5-20)$ & $8(4-30)$ \\
\hline IP number median (range) & $1(1-3)$ & $1(1-2)$ & $1(1-3)$ \\
\hline Endoscopic biopsy & $18(50)$ & $12(70.5)$ & $30(56.6)$ \\
\hline Biopsy not diagnostic & $4(22.2)$ & $2(11.7)$ & $6(20)$ \\
\hline IP pathology confirmation & $14 / 18(77.7)$ & $10 / 12(83.3)$ & $24(80)$ \\
\hline \multicolumn{4}{|l|}{ Other endoscopic findings } \\
\hline \multicolumn{4}{|c|}{ 1. Esophagus pathology $(n=53)$} \\
\hline a. Normal & $33(91.6)$ & $12(70.5)$ & $45(84.9)$ \\
\hline b. Reflux esoph. & 0 & $5(29.4)$ & $5(10)$ \\
\hline c. Varices & $1(2)$ & 0 & $1(2)$ \\
\hline d. Barrett & $1(2)$ & 0 & $1(2)$ \\
\hline e. Pill esoph. & $1(2)$ & 0 & $1(2)$ \\
\hline \multicolumn{4}{|l|}{ 2. LES evaluation $(n=53)$} \\
\hline a. Normal & $29(80.5)$ & $9(52.9)$ & $38(73.5)$ \\
\hline b. Incompetant & $7(19.4)$ & $7(41.1)$ & $14(26.4)$ \\
\hline c. Hiatal Hernia & 0 & $1(5.8)$ & $1(1.8)$ \\
\hline \multicolumn{4}{|l|}{ 3. Gastritis $(n=40)$} \\
\hline a. Antral gastritis & $18(50)$ & $11(64.7)$ & $29(54.7)$ \\
\hline b. Pangastritis & $8(22.2)$ & $3(17.6)$ & $11(20.7)$ \\
\hline \multicolumn{4}{|l|}{ 4. H. pylori $(\mathrm{n}=22)$} \\
\hline a. Positive & $7(58.3)$ & $5(50)$ & $12(54.5)$ \\
\hline b. Negative & $5(41.6)$ & $5(50)$ & $10(45.4)$ \\
\hline Distal esoph. located IP & $2(4)$ & 0 & $2(4)$ \\
\hline
\end{tabular}

*Values are presented as $n(\%)$.

Esoph: Esophagitis; IP: Inlet patch, LES: Lower esophageal sphinchter; H pylori.: Helicobacter pylori; Pathol: Pathology. 


\begin{tabular}{|c|c|c|c|c|}
\hline & IP Size mm, median (range) & $\mathbf{P}$ & IP number $n$, median (range) & $\mathbf{P}$ \\
\hline Age, years $\geq 50 /<50$ & $6(4-20) / 8(4-30)$ & 0.247 & $1.0(1-3) / 1.0(1-3)$ & 0.720 \\
\hline Gender F/M & $7.5(4-30) / 8(5-20)$ & 0.423 & $1(1-3) / 1(1-2)$ & 0.773 \\
\hline Globus sensation +/- & $8(4-30) / 8(5-10)$ & 0.807 & $1(1-3) / 1(1-2)$ & 0.586 \\
\hline GERD +/- & $8(4-30) / 7(6-10)$ & 0.816 & $1(1-3) / 1(1-2)$ & 0.334 \\
\hline Gastrit +/- & $7.0(5-30) / 7.5(5-10)$ & 0.378 & $1.0(1-3) / 1.0(1-3)$ & 0.169 \\
\hline H. pylori+/- & $7.5(5-20) / 7.5(5-10)$ & 0.609 & $1.0(1-3) / 1.0(1-3)$ & 0.085 \\
\hline
\end{tabular}

GERD: Gastroesophageal reflux disease, IP: Inlet patch, F: Female, M: Male, H. pylori: Helicobacter .pylori.

\begin{tabular}{|c|c|c|c|c|c|c|c|}
\hline & Age & GERD & IP Size & IP No & Incomp. Cardia & Antral Gastritis & H. pylori \\
\hline \multirow[t]{2}{*}{ GERD } & & & 0.052 & 0.122 & $0.539 * *$ & 0.173 & 0.059 \\
\hline & & & 0.712 & 0.385 & 0.000 & 0.225 & 0.793 \\
\hline \multirow[t]{2}{*}{ Age } & & 0.054 & -0.216 & -0.104 & 0.124 & -0.050 & -0.303 \\
\hline & & 0.702 & 0.124 & 0.461 & 0.380 & 0.729 & 0.171 \\
\hline \multirow[t]{2}{*}{ Globus sensat. } & -0.100 & -0.146 & -0.054 & 0.014 & -0.043 & -0.007 & 0.194 \\
\hline & 0.481 & 0.297 & 0.702 & 0.923 & 0.760 & 0.959 & 0.388 \\
\hline
\end{tabular}

The upper values show the correlation coefficient $r$, the lower values show the $p$ value.

IP: Inlet patch, GERD: Gastroesophageal reflux disease; H. pylori: Helicobacter pylori. Incomp: Incompatible, No: Number;

\section{Relationship of Esophageal IP Size and Number With Age, Gender and Other Symptoms}

Comparison of endoscopic IP size and number with age, gender, globus sensation, endoscopic gastroesophageal reflux disease (GERD) and Helicobacter pylori (H. pylori) findings are shown in Table 3.

\section{Correlation Between Globus Sensation and Endoscopic Findings}

The relationship between endoscopic GERD, incompetant cardia, globus sensation, antral gastritis and $H$. pylori in patients are shown in Table 4.

We attributed the upper GI bleeding cause to the hemorrhagic IPs in the proximal esophagus in endoscopic evaluation in a patient who is undergoing dialysis, and followed up in intensive care unit. We found a histologically confirmed IP in the distal esophagus in another patient who presented with a globus sensation,

\section{DISCUSSION}

In the present study, we evaluated demographic and endoscopic findings of 53 cases with esophageal IP. The majority of patients with esophageal IP were women (68\%). The age distribution of the patients included the entire adult age group from 19 to 83 years. In endoscopic evaluation, IP median size was $8 \mathrm{~mm}$, range (4-30), IP median number was 1, range (1-3). Biopsy was performed on $30(56.6 \%)$ patients. We found that there is no additional esophageal pathology in 42 (79.2\%), normal LES in 37 (69.8\%), incompetent in 13 (24.5), and hiatal hernia in 1 (1.8\%) patient. In 12 (54.5\%) of 22 endoscopic biopsies $H$. pylori was positive. the IP location was in the distal esophagus in 2 (3.7\%) patients, (Table $1,2,3)$. In this study, the majority of our patients were asymptomatic (73.5\%) and we detected the majority of the lesions incidentally during endoscopic evaluation. Commonly reported symptoms (globus sensation, laryngopharengeal reflux and dysphagia) were in 10 (27.7\%) of women and $4(23.5 \%)$ of men $(3,4)$. Globus sensation has been noted as the most common symptom in symptomatic patients (11).

It is important that those with globus complaints should be sought carefully with strong suspicion. Inlet patch must be carefully searched during endoscopic evaluation, otherwise it may be missed (12-14). It may not even be noticed during peristalsis in the middle esophagus. Espe- 
cially when the tubular structure is vertical in the middle esophagus. We detected IP in the distal esophagus in two patients. A case report in the distal esophagus confused with Barrett's esophagus has been reported (15). The suspicion of a relationship between inlet patch and Barrett's esophagus has been investigated in many studies and conflicting results were reported (2). Avidan et al. indicated that this situation may be due to a common embryological etiology. (16). In our study, 9 (64.2\%) of a total of 14 symptomatic patients had globus complaints (Table 1). Most of them with globus sensation were women (77.7\%). Interestingly, we did not find a significant relationship between IP size $(p=0.807)$ and IP numbers $(p=0.586)$ of 9 patients with globus sensation and 44 patients without it (Table 3). Ciocalteu et al. also observed such a relationship (11).

In other studies, it has been stated that esophageal IP is more common in men (17). However, in this study, we found that the rate of esophageal IP was more common in women (68\%). Akbayır et al. also indicated that the rate of women was higher in their study (14). In a review by Ciocelteu et al, IP was more common in women and can appear as hypochondria when it is associated with anxiety (11). We found that the presence of more specific symptoms and the globus sensation were approximately 3 times higher in women then men (Table 1). Although the esophageal IP rate and specific symptoms were higher in women and we did not find any difference between women and men in terms of the size and number of IPs (Table 1).

In our study, we found that the size and number of esophageal IP were not different between women and men and also patients over 50 years age or not. Although we did not find a significant relationship among the size and number of IPs and the presence of globus sensation, GERD and H. pylori (Table 3 and 4). As seen in Figure 1 and Table 2, the range between the sizes of the esophageal IPs was between $4 \mathrm{~mm}$ and $30 \mathrm{~mm}$. It is surprising that there is no link between dimensions, symptomatology and clinical findings. The second factor is whether the dimensions vary over time, and perhaps dimensions may have a role in the malignant potential that needs to be determined.

Chung et al. concluded that the clinical relevance of esophageal IP and its association with GERD need further investiagation (18). However, nonerosive GERD was more closely associated with globus sensation than esophageal IP (19). In the correlation analysis between age, IP size and number, globus sensation, GERD, incompetant cardia and the presence of $H$. pylori, we found only a significant correlation between incompetant cardia and GERD, but there is no significance between other parameters (Table 4). Neumann et al. stated that there is a significant relationship between proximal esophageal IPs and adenocarcinomas arising from Barrett's mucosa (17). Yüksel et al. also stated that there is a predisposition between GERD, Barrett and IP (20). Here, contrary to other studies, the lack of a significant correlation between globus sensation, GERD and incompetant cardia suggests that esophageal IPs does not have an organic connection with GERD.

We did not find any signs of malignancy in patients with esophageal IP in endoscopic observation and in patients who received biopsy for confirmation. Alagöz et al. reported two cases diagnosed with hyperplastic polyps and adenocarcinoma developing on the background of IP (21). In the literature, there is a small number of case reports about proximal esophagus adenocarcinoma developed from the IP background $(22,23)$. However, a comprehensive study of 398 patients diagnosed with esophageal adenocarcinoma reported that adenocarcinoma developed from the IP background only in 5 of them (24).

The limitation of our study is that it's retrospective nature. Due to its retrospective design, the questioning of symptoms are generally based on the patient's statement in the procedure report. However, we think that direct questioning of the presence of specific symptoms (globus sensation, laryngopharengeal reflux and dysphagia) would be more accurate.

Esophageal IP was encountered mostly in female patients (68\%). IP median sizes are $8 \mathrm{~mm}$ and we did not find any difference between both gender. In addition, we did not find a relationship between IP sizes and the presence of symptoms. Also, we did not find any evidence of malignancy in esophageal IP biopsies.

Conflicts of Interest: All authors declare that there is no conflicts of interest.

Ethics: Ethics committee approval was received from Bezmialem University, Ethics Committee of Non-Interventional Research (26.02.2021-03-62). 


\section{REFERENCES}

1. Schumidt FFA. De mammlium oesophage atque ventriculo, Inaugural dissertation. Bathenea: Halle, 1805.

2. Rusu R, Ishaq S, Wong T, Dunn JM. Cervical inlet patch: new insights into diagnosis and endoscopic therapy. Frontline Gastroenterol 2018;9:214-20.

3. Chong VH. Clinical significance of heterotopic gastric mucosal patch of the proximal esophagus. World J Gastroenterol 2013;19:331-8.

4. Akbayır N, Sökmen HM, Çalış $A B$, et al. Heterotopic gastric mucosa in the cervical esophagus: Could this play a role in the pathogenesis of laryngopharyngeal reflux in a subgroup of patients with posterior laryngitis? Scand J Gastroenterol 2005;40:1149-56.

5. Galmiche JP, Clouse RE, Balint A, et al. Functional esophageal disorders. Gastroenterology 2006;130:1459-65.

6. Aziz Q, Fass R, Gyawali CP, et al. Esophageal disorders. Gastroenterology 2016;150:1368-79.

7. Yamada T, Tsuji A, Onoue S, et al. Acid suppressive therapy improved symptoms due to circumferential cervical inlet patch with proton pumps $\left(\mathrm{H}^{+} / \mathrm{K}^{+}\right.$-ATPase). World J Clin Cases 2017;5:403-6

8. Meining A, Bajbouj M. Gastric inlet patches in the cervical esophagus: what they are, what they cause, and how they can be treated. Gastrointest Endosc 2016;84:1027-9.

9. Bajbouj M, Becker V, Eckel F, et al. Argon plasma coagulation of cervical heterotopic gastric mucosa as an alternative treatment for globus sensations. Gastroenterology 2009;137:440-4.

10. Klare $P$, Meining $A$, von Delius $S$, et al. Argon plasma coagulation of gastric inlet patches for the treatment of globus sensation: It is an effective therapy in the long term. Digestion 2013;88:165-71.

11. Ciocalteu A, Popa P, Ionescu M, Gheonea DI. Issues and contraversies in esophageal inlet patch. World J Gastroenterol 2019;25:4061-73.

12. Sahin G, Adas $G$, Koc B, et al. Is cervical inlet patch important clinical problem ? Int J Biomed Sci 2014;10:129-35.

13. Korkut E, Bektas M, Savas B, et al. Awareness of the endoscopist affects detection rate of heterotopic gastric mucosa in esophagus. Indian J Gastroenterol 2009;28:75-6.
14. Akbayır N, Alkım C, Erdem L, et al. Heterotopic gastric mucosa in the cervical esophagus (inlet patch): Endoscopic prevalence, histological and clinical characteristics. J Gastroenterol Hepatol 2004;19:891-6.

15. Mungan Z. Is it Barrett's esophagus or gastric heterotopia? Case Rep Gastroenterol 2014;8:282-5.

16. Avidan B, Sonnenberg A, Chejfec G, Schnell TG, Sontag S. Is there a link between cervical inlet patch and Barrett's esophagus? Gastrointest Endosc 2001;53:717-21.

17. Neumann WL, Lujan GM, Genta RM. Gastric heterotopia in the proximal oesophagus ("inlet patch"): Association with adenocarcinomas arising in Barrett mucosa. Dig and Liver Dis 2012;44:292-6.

18. Chung CS, Lin CK, Liang CC, Hsu WF, Lee TH. Intentional examination of esophagus by narrow-band imaging endoscopy increases detection rate of cervical inlet patch. Dis of Esoph 2015;28:666-72.

19. Hori K, Kim Y, Sakurai J, et al. Non-erosive reflux disease rather than cervical inlet patch involves globus. J Gastroenterol 2010;45:113845.

20. Yüksel I, Üsküdar O, Köklü S, et al. Inlet patch: Associations with endoscopic findings in the upper gastrointestinal system. Scand J Gastroenterol 2008;43:910-4

21. Alagozlu H, Ergun $M$, Cindoruk $M$, et al. The rare presentations of a large polyp and an esophageal carcinoma in heterotropic gastric mucosa: a case series. J of Med Case Rep 2007;1:127.

22. Hoshino A, Otuka Y, Nara S, Harihara Y, Konishi T. A case of primary adenocarcinoma of the cervical esophagus arising from the ectopic gastric mucosa. Esophagus 2007;4:83-6.

23. Ajmal S, Young JS, Ng T. Adenocarcinoma arising from cervical esophageal gastric inlet patch. J Thorac Cardiovasc Surg 2015;149:1664-5

24. Orosey M, Amin M, Cappell MS. A 14- year study of 398 esophageal adenocarcinomas diagnosed among 156,256 EGDs performed at two large hospitals: An inlet patch is proposed as a significant risk factor for proximal esopohageal adenocarcinoma. Dig Dis Sc 2018;63:452-65. 